\title{
MANAJEMEN SARANA DAN PRASARANA PEMBELAJARAN BAHASA ARAB DI MAN 3 TULUNGAGUNG
}

\author{
Siti Mu'alifah'1) \\ 1)Institut Agama Islam Sunan Kalijogo Malang \\ 1)Syafaallif@gmail.com
}

\begin{abstract}
Abstrak: Sarana pendidikan adalah semua fasilitas yang diperlukan dalam proses belajar mengajar, baik yang bergerak maupun yang tidak bergerak agar pencapaian tujuan pendidikan berjalan dengan lancar, teratur, efektif dan efesien. Prasarana adalah fasilitas yang secara tidak langsung menunjang jalannya proses pendidikan, seperti: halaman, kebun atau taman sekolah, jalan menuju ke sekolah, tata tertib sekolah, dan sebagainya. Kegiatan manajemen sarana dan prasarana di MAN 3 Tulungagung yaitu meliputi: (1) Pengadaan, Adapun pada kegitan pengadaan barang di MAN 3 Tulungagung untuk memperoleh dananya yaitu dibantu oleh pemerintah dan sekolah tinggal meminta izin atau membuat proposal untuk memperoleh dana dan digunakan membeli barang yang dibutuhkan sekolah tersebut. (2) Penggunaan, Setelah dilakukaan pengadaan sarana dan prasarana selanjutnya barang digunakan secara maksimal dengan tujuan untuk menunjang pencapaian tujuan lembaga. (3) Pemeliharan, pemeliharaan barang yang dilakukan MAN 3 Tulungagung terhadap semua fasilitas yang ada disediakan anggaran sendiri. (4) Peniadaan/Penghapusan, dalam hal peniadaan, lembaga tidak begitu saja membuang atau menghapus barangbarang yang sudah rusak atau sudah tidak bisa terpakai.
\end{abstract}

Kata Kunci: Sarana, Pra Sarana, MAN 3 Tulungagung

$$
\begin{aligned}
& \text { مستخلص البحث: المرافق التعليمية هي كل التسهيلات المحتاجة في عملية التعليم } \\
& \text { والتعلم، محركة وغير محركة لتحقيق الأهداف التعليمية سلاسة ومنظمة وفعالية وكفاءة. } \\
& \text { اما الوسائل التعليمية هي التسهيلات التي غير مباشرة تدعم العملية التعليمية ، مثل: } \\
& \text { الفناء والحديقة، والطريق الى المدرسة، ونظام المدرسة ، وغير ذلك. } \\
& \text { انشطة المرافق والوسائل التعليمية في المدرسة الثانوية الإسالامية الحكومية الثالثة تولونج } \\
& \text { اكونج كما يلي: (1) التدبير ، في هذه الأنشطة، المدرسة الثانوية الإسلامية الحكومية } \\
& \text { الثالثة تولونج اكونج، لاكتساب على الأموال وهو بمساعدة الحكومة والمدرسة تستأذن } \\
& \text { او تطلب الاقتراح للحصول على الأموال وتستخدامها لشراء الآثاث التي تحتاجها } \\
& \text { المدرسة. (2) الاستخدام ، بعد تدبير المرافق والوسائل التعليمية هو استخدام الآثاث } \\
& \text { لتحقيق أهداف المؤسسة. (3) الحفظ، حفظ الحوائج التي تقام المدرسة الثانوية } \\
& \text { الإسلامية الحكومية الثالثة تولونج اكونج لجميع المرافق الموجودة يتفوفر بنفسها. (4) }
\end{aligned}
$$




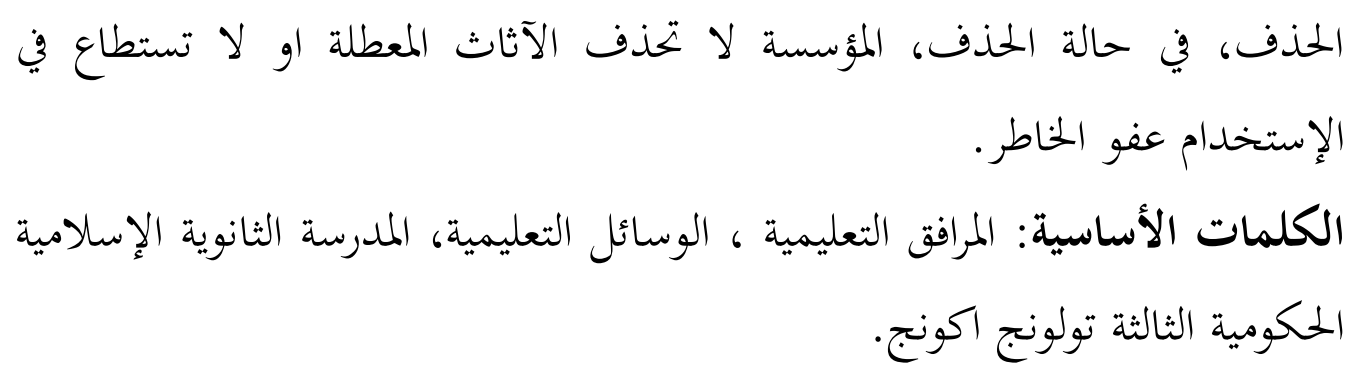

\section{PENDAHULUAN}

Aspek sarana dan prasarana pendidikan berkenaan dengan fasilitas dan kemudahankemudahan dalam pelaksanaan pendidikan yang tersedia. Sarana dan prasarana pendidikan masih sangat tergantung pengadaannya dari pemerintah pusat, sementara pendistribusiannya belum terjamin merata sampai ketujuannya sehingga kemandirian dan rasa turut bertanggung jawab daerah masih dirasakan kurang maksimal. Permasalahan-permasalahan yang menyangkut fasilitas pendidikan ini, erat kaitannya dengan kondisi tanah, bangunan dan perabot yang menjadi penunjang terlaksananya proses pendidikan. Dalam aspek tanah pendidikan, berkaitan dengan status hukum kepemilikan tanah yang menjadi tempat pendidikan, letaknya yang kurang memenuhi persyaratan lancarnya proses pendidikan (sempit, ramai, terpencil, kumuh, labil, dan lain-lain). Aspek bangunan berkenaan dengan kondisi gedung sekolah yang kurang memadai untuk lancarnya proses pendidikan (lembab, gelap, sempit, rapuh, bahkan banyak yang sudah ambruk, dan lain-lain) sampai membahayakan keselamatan. Aspek perabot berkenaan dengan sarana yang kurang memadai bagi pelaksanaan proses pendidikan (meja-kursi yang reyot, alat peraga yang kurang lengkap, buku paket yang tidak cukup, sarana kesehatan kurang memadai, dan lain-lain), termasuk fasilitas untuk kebutuhan ekstrakurikuler. Oleh karena itu, pada pembahasan makalah ini penulis mengungkapkan pengalaman tentang MAN 3 Tulungagung mengenai pengelolaan sarana dan prasarana pendidikan yang tersedia, baik sarana prasarana secara umum maupun sarana prasarana terkait pembelajaran bahasa Arab.

\section{METODE PENELITIAN}

\subsection{Jenis dan Sumber Data}

Jenis penelitian yang digunakan adalah penelitian kualitatif dengan menggunakan penelitian lapangan (field research) yaitu penelitian yang dilakukan 
ditempat terjadinya gejala-gejala yang diteliti, data-data yang diperoleh dari hasil pengamatan baik secara langsung maupun tidak langsung (Zainal Arifin,2015:18).

Menurut Moleong yang dikutip oleh Haris Herdiansyah, penelitian kualitatif yaitu penelitian yang bermaksud memahami fenomena tentang apa yang dialami oleh subjek penelitian, misalnya perilaku, persepsi, motivasi, tindakan, dan lain sebagainya. Secara holistik dengan cara deskripsi dalam bentuk kata-kata dan bahasa pada suatu konteks khusus yang alamiah dan dengan memanfaatkan berbagai metode alamiah. ${ }^{1}$

Pendekatan penelitian kualitatif ini bersifat deskriptif. Penelitian deskriptif adalah pendekatan yang dimaksudkan untuk menyelidiki keadaan, kondisi atau hal lain-lain yang sudah disebutkan, yang hasilnya menghasilkan data deskriptif berupa kata-kata tertulis atau lisan dari orang-orang dan perilaku yang diamati. ${ }^{2}$

Penelitian deskriptif yang penulis lakukan adalah berupaya untuk menggambarkan bagaimana penerapan manajemen sarana dan prasarana Pendidikan Bahasa arab di MAN 3 Tulungagug dulunya bernama MAN Rejotangan dan Madrasah Aliyah Negeri (MAN) Rejotangan

\section{HASIL DAN PEMBAHASAN}

\section{Sejarah MAN 3 Tulungagung}

MAN 3 Tulungagug dulunya bernama MAN Rejotangan dan Madrasah Aliyah Negeri (MAN) Rejotangan tersebut didirikan oleh yayasan Pendidikan Islam Pesantren Sabilil Muttaqien (YPI PSM) Tanen Rejotangan Tulungagung pada tahun 1958 yang mula-mula bernama Madrasah Islam Menengah (MIM). Pada tahun 1969 MIM berubah menjadi Madrasah Aliyah Pesantren Sabilil Muttaqien / MA PSM.

Tahun 1980 Madrasah Aliyah Pesantren Sabilil Muttaqien /MA PSM berubah menjadi Fillialnya MAN I Tulungagung.

\footnotetext{
${ }^{1}$ Haris Herdiansyah, Metodologi Penelitian Kualitatif untuk IImu-IImu Sosial, 2004, PT. Salemba Humanika, h. 9

${ }^{2}$ Suharsimi Arikunto, Prosedur Penelitian: Suatu Pendekatan Praktik. 2013, Jakarta: Rineka Cipta, hal. 3
} 
Akhirnya pada tanggal 25 Nopember 1995 turun SK Kanwil Departemen Agama Propinsi jawa Timur nomor : 515A/1995 tentang penegerian MA Fillial menjadi Madrasah Aliyah Negeri Rejotangan dan pada tahun 2010 berubah menjadi MAN 3 Tulungagung.

Yang pernah menjabat sebagi Kepala Madrasah adalah:
a) H. Afandi sejak berdiri sampai tahun 1991
b) Drs. Masrur, tahun 1991 sampai 1996
c) Drs. H. Miftah, tahun 1996 sampai 2000
d) Drs. H. Mukadji, tahun 2000 sampai 2003
e) Drs. Masrur, tahun 2003 sampai 2005
f) Drs. H. Marjuni, M.Pd, tahun 2005 sampai 2009
g) Drs. H. Slamet Riyadi, M.Pd, tahun 2009 sampai sekarang

\section{Profil MAN 3 Tulungagung}
a) Nama Sekolah
: MAN 3 Tulungagung
b) Kelurahan
: Tanen
c) Kecamatan
: Rejotangan
d) Kotamadya
: Tulungagung
e) Propinsi
: Jawa Timur
f) Kode Pos
: 66293
g) No. Telpon
: (0355) 371113
h) No. Fax : (0355) 5236540
i) Nama Kepala Sekolah
: Drs. Khoirul Huda, M.Ag
j) Tahun berdiri
: tahun 1991
k) Website : manrejotangan.sch.id
l) E-mail : manrejotangan@yahoo.co.id

MAN 3 Tulungagung terletak di jalan Supriadi Tanen, Rejotangan, Tulungagung. Dengan Visinya yaitu "UNGGUL DALAM IPTEK YANG BERWAWASAN IMTAQ, TERAMPIL YANG ISLAMI" untuk mencapai visi tersebut ada beberapa indikator sebagai berikut.

a) Memiliki Standar Kompetensi Lulusan (SKL) yang telah ada dengan mengadopsi SKL dari negara maju.

b) Menerapkan kurikulum bertaraf internasional untuk mata pelajaran Matematika, IPA dan Bahasa Inggris. 
c) Mengembangkan Proses Pembelajaran dengan berbagai strategi pembelajaran yang Interaktif, Inspiratif dan Menyenangkan yang meliputi 3 kegiatan (Eksplorasi, Elaborasi dan Konfirmasi).

d) Meningkatkan kompetensi dan kemampuan berbahasa inggris bagi tenaga pendidik dan tenaga kependidikan.

e) Melengkapi sarana dan prasarana yang mengarah pada standar internasional.

f) Mengembangkan manajemen madrasah secara professional dan mengarah pada manajemen berstandar internasional.

g) Mampu menggali dana untuk pembiayaan klas Rintisan Madrasah Bertaraf Iinternasional (RMBI) dengan melibatkan orangtua siswa, komite madrasah dan pihak lain yang relevan.

h) Mengembangkan standar penilaian pendidikan yang disesuaikan dengan tuntutan kurikulum internasional.

i) Bermitra dengan madrasah/sekolah unggul di dalam maupun di luar negeri.

j) Menghasilkan lulusan yang berkompetensi dan dapat diterima di perguruan tinggi yang berkualitas di dalam maupun di luar negeri.

k) Menghasilkan outcome yang dapat terserap ke dalam dunia kerja dan diterima masyarakat.

l) Menyelenggarakan Program Kelas Akselerasi.

Serta Misinya adalah sebagai berikut.

a) Mewujudkan SKL dari negara maju antara lain dari Madrasah Aliyah Al Irsyad Al Islamiyah Singapura.

b) Menambah jam pembelajaran mata pelajaran matematika, IPA (Fisika, Kimia dan Biologi) dan Bahasa Inggris.

c) Melaksanakan proses pembelajaran secara efektif dan efisien yang interaktif, inspiratif dan menyenangkan yang meliputi 3 kegiatan (Eksplorasi, Elaborasi dan Konfirmasi).

d) Mengadakan Pelatihan Bahasa Inggris bagi tenaga pendidik dan tenaga kependidikan oleh relawan dari Peace Corp Amerika Serikat Mr. Bart Thanhaus.

e) Melengkapi sarana dan prasarana klas RMBI dan Ma'had (Asrama).

f) Menerapkan Manajemen Berbasis Madrasah (MBM) secara professional

g) Penggalian dana kusus klas RMBI.

h) Melaksanakan penilaian yang mengacu pada Standar Penilaian Pendidikan. 


\section{QRPDENIKa \\ Jurnal Manajemen Pendidikan Islam}

INSTITUT AGAMA ISLAM SUNAN KALIJOGO MALANG

P-ISSN 2622-9293 / E-ISSN 2721-9658

Volume 3 Nomor 1 Juni 2021

i) Menjalin kemitraan dengan Madrasah/Sekolah Unggul di dalam negeri dan Madrasah Aliyah Al Irsyad Al Islamiyah Singapura.

j) Mengenalkan madrasah ke sejumlah Perguruan Tinggi Negeri Se-Indonesia.

k) Mengadakan kerjama sama ke Perusahaan-Perusahaan.

l) Mulai Tahun Pelajaran 2011/2012 menyelenggarakan program kelas akselerasi.

Gambar profil MAN 3 Tulungagung dan beberapa aktivitas di dalamnya

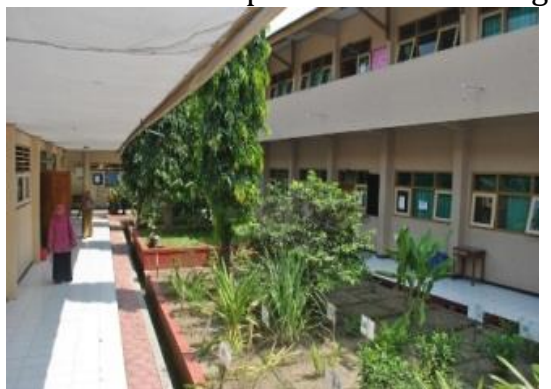

Beberapa ruang kelas di MAN 3 Tulungagung

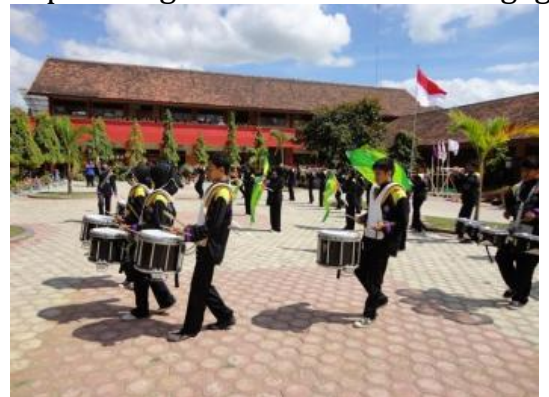

Kegiatan Drumb band di halamn MAN 3 Tulungagung

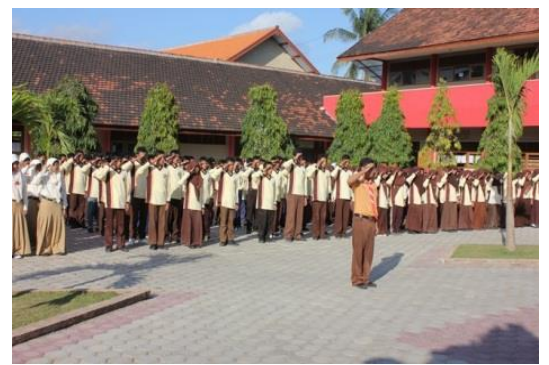

Upacara bendera di halaman MAN 3 Tulungagung

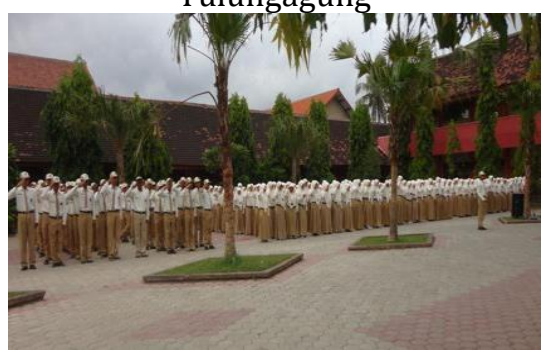

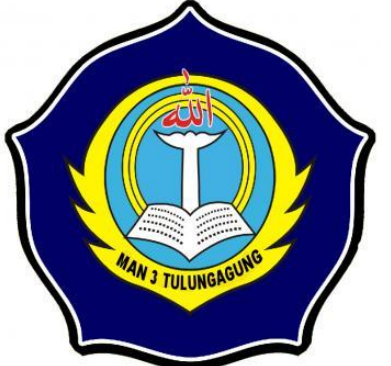

Logo MAN 3 Tulungagung

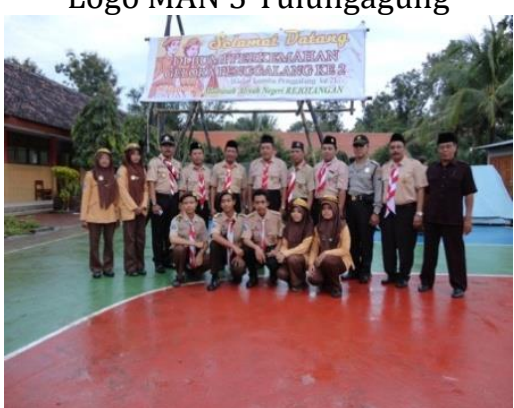

Panitia lomba pramuka penggalang sedang mengambil gambar (foto) di lapangan basket MAN 3 Tulungagung

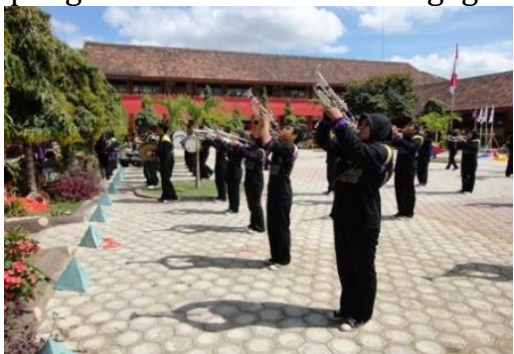

Kegiatan Drumb band di halaman MAN 3 Tulungagung

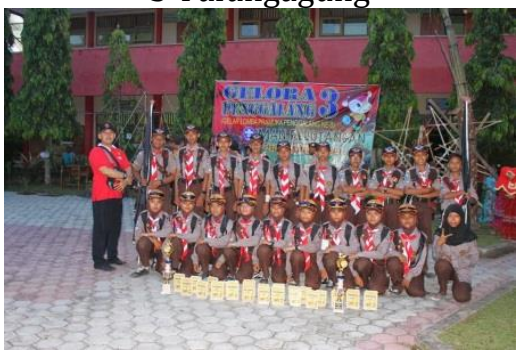




\section{คКคDEMIKค \\ Jurnal Manajemen Pendidikan Islam}

INSTITUT AGAMA ISLAM SUNAN KALIJOGO MALANG

P-ISSN 2622-9293 / E-ISSN 2721-9658

Volume 3 Nomor 1 Juni 2021

Upacara bendera di halaman MAN 3 Tulungagung
Pemenang lomba pramuka penggalang yang mengambil foto MAN 3 Tulungagung

\section{B. Kondisi Sarana Prasarana di MAN 3 Tulungagung}

\section{Kondisi Sarana di MAN 3 Tulungagung}

Sarana pendidikan adalah semua fasilitas yang diperlukan dalam proses belajar mengajar, baik yang bergerak maupun yang tidak bergerak agar pencapaian tujuan pendidikan dan berjalan dengan lancar, teratur, efektif dan efesien. ${ }^{3}$ Adapun menurut pengalaman penulis selama menjadi siswi di MAN 3 Tulungagung, sarana yang ada di MAN 3 Tulungagung sudah lengkap, hal ini dibuktikan dengan terdapatnya beberapa sarana seperti bangku, meja, papan tulis, penghapus, spidol, dan alat-alat lain yang mendukung kerja seluruh warga sekolah. Adapun sarana MAN 3 Tulungagung diantaranya:

a) Perabot, yang termasuk kedalam perabot ini seperti meja, kursi, papan tulis, lemari, tong sampah. Namun tidak ada data yang akurat untuk jumlah pasti keseluruhan perabot. Untuk meja dan kursi, setiap ruangan disesuaikan dengan jumlah peserta didik. Namun yang unik dari MAN 3 Tulungagung adalah hampir di setiap kelas terdapat cermin hal ini bisa digunakan baik oleh siswa ataupun guru.

b) Peralatan pendidikan, untuk peralatan pendidikan diantaranya terdapat komputer yang terpusat di ruang lab.komputer sebanyak 45 unit.

c) Media pendidikan, media pendidikan digunakan untuk memperlancar proses informasi dalam proses pembelajaran. Media yang digunakan diantaranya adalah Infocus, untuk kali ini infocus yang terdapat di MAN 3 Tulungagung baru terdapat 4 buah. Selain menggunakan media elektronik, lembaga juga menggunakan sarana majalah dinding (mading). Mading di sekolah terdapat sekitar 4 mading, tiga diantaranya digunakaan oleh sekolah, dan satu digunakan oleh siswa sebagai sarana dalam pembelajaran jurnalistik. Selain itu terdapat juga satu ruangan khusus yang dinamakan ruang multi media yang berfungsi sebagai media pembelajaran supaya lebih menyenangkan.

d) Buku. Untuk menunjang proses pembelajaran, terdapat beberapa buku yang menjadi rujukan. Semua buku terpusat pada perpustakaan. Adapun kualifikasi buku yang terdapat di MAN 3 Tulungagung tersaji dalam tabel berikut.

${ }^{3}$ B.Sury dan Subroto, Dimensi-dimensi Administrasi Pendidikan di Sekolah, (Jakarta :Bina Aksara, 1988), Hlm. 75. 


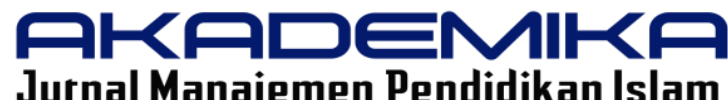

Jurnal Manajemen Pendidikan Islam

INSTITUT AGAMA ISLAM SUNAN KALIJOGO MALANG

P-ISSN 2622-9293 / E-ISSN 2721-9658

Volume 3 Nomor 1 Juni 2021

\begin{tabular}{c|c|c|c|c|}
\hline No. & Jenis Buku & Judul & Kuantitas & Kualitas \\
\hline 1. & Karya Umum & 4 & 30 & Baik \\
\hline 2. & Agama & 2 & 67 & Baik \\
\hline 3. & Ilmu Pengetahuan Sosial & 13 & 717 & Baik \\
\hline 4. & Ilmu Pengetahuan Alam & 14 & 1300 & Baik \\
\hline 5. & Bahasa & 38 & 1961 & Baik \\
\hline 6. & Sejarah & 6 & 376 & Baik \\
\hline & Jumlah & 77 & $\mathbf{4 4 5 1}$ & \\
\hline
\end{tabular}

Dengan sejumlah buku tersebut seluruh warga bisa mengakses dan menambah wawasannya di perpustakaan sekolah.

e) Bahan habis pakai, untuk bahan habis pakai ini memang tidak ada data yang akurat, namun untuk jenisnya yang terdapat di MAN 3 Tulungagung adalah spidol, tinta, kertas dan lain sebagainya. Berhubung seluruh ruang kelas yang ada di MAN 3 Tulungagung ini telah menggnakan White Board, maka penggunaan spidol dan tinta menjadi anggaran yang ada dalam pengeluaran bulanan bagian sarana prasarana.

\section{Kondisi Prasarana di MAN 3 Tulungagung}

Prasarana adalah fasilitas yang secara tidak langsung menunjang jalannya proses pendidikan, seperti: halaman, kebun atau taman sekolah, jalan menuju ke sekolah, tata tertib sekolah, dan sebagainya. ${ }^{4}$ Adapun menurut E. Mulyasa yang dimaksud dengan prasarana pendidikan adalah fasilitas yang secara tidak langsung menunjang jalannya suatu proses pendidikan atau pengajaran di suatu lembaga pendidikan, seperti gedung, ruang kelas, halaman, kebun sekolah, jalan menuju sekolah, dan sebagainya. Namun, apabila prasarana tersebut digunakan secara langsung untuk kegiatan belajar mengajar, misalnya kebun sekolah digunakan untuk kegiatan belajar biologi maka kebun sekolah menjadi sarana pendidikan. Keberadaan prasarana ini memang tidak wajib, tapi menjadi pendukung dalam proses belajar mengajar. ${ }^{5}$

Adapun Prasarana yang ada di MAN 3 Tulungagung bisa diihat dari tabel berikut.

\begin{tabular}{c|c|c|c|}
\hline No & RUANG & JUMLAH & KETERANGAN \\
\hline 1 & Ruang kelas & 27 & Baik \\
\hline 2 & Ruang kepala sekolah & 1 & Baik \\
\hline 3 & Ruang guru & 1 & Baik \\
\hline 4 & Ruang serba guna & 1 & Baik \\
\hline 5 & Ruang wakil kepala sekolah & 1 & Baik \\
\hline
\end{tabular}

${ }^{4}$ Piet dan A.Sahertian, Dimensi Administrasi Pendidikan, (Surabaya:Usaha Nasional, 1994), hlm. 172.

${ }^{5}$ Baharudin \& Moh. Makin, Manajemen Pendidikan Islam Trnsformasi Menuju Sekolah/Madrasah Unggul, (Yogyakarta : UIN-Maliki Press, 2010), hlm.84. 


\begin{tabular}{|c|c|c|c|}
\hline 6 & Ruang Tata usaha & 1 & Baik \\
\hline 7 & Ruang koperasi & 1 & Baik \\
\hline 8 & Ruang BK & 1 & Baik \\
\hline 9 & Ruang UKS & 1 & Baik \\
\hline 10 & Ruang piket & 1 & Baik \\
\hline 11 & Ruang satpam & 1 & Baik \\
\hline 12 & Ruang perpustakaan & 1 & Baik \\
\hline 13 & Ruang multimedia & 1 & Baik \\
\hline 14 & Ruang lab.komputer & 2 & Baik \\
\hline 15 & Ruang komite sekolah & 1 & Baik \\
\hline 16 & Dapur & 1 & Baik \\
\hline 17. & Laboratorium fisika & 1 & Baik \\
\hline 18. & Lab. Biologi & 1 & Baik \\
\hline 19. & Lab.Kimia & 1 & Baik \\
\hline 20. & Ruang life skill & 1 & Baik \\
\hline 21. & Ruang Ekskul & 6 & Baik \\
\hline 22. & Rumah penjaga sekolah & 4 & Baik \\
\hline 23. & Gudang & 1 & Baik \\
\hline 24. & WC kelas X, XI, dan XII & 24 & Baik \\
\hline 25. & Masjid & 1 & Baik \\
\hline 26. & Lapangan basket & 1 & Baik \\
\hline 27. & Lapang voley & 1 & Baik \\
\hline 28. & Halaman & 2 & Baik \\
\hline 29. & Taman & 5 & Baik \\
\hline 30. & Tempat parkir & 4 & Baik \\
\hline 31. & Koridor & 1 & Baik \\
\hline 32. & Kantin sekolah & 6 & Baik \\
\hline 33. & Ruang Lab. Bahasa & 1 & Baik \\
\hline 34. & Mushola & 1 & Baik \\
\hline 35. & Lain-lain & & \\
\hline \multicolumn{2}{|c|}{ JUMLAH } & 105 & \\
\hline
\end{tabular}

Secara keseluruhan sarana prasarana yang ada di MAN 3 Tulungagung terawat dengan baik. Hal ini bisa terlihat dengan kondisi sekolah yang nyaman dan asri.

\section{Manajemen Sarana Prasarana di MAN 3 Tulungagung}

Manajemen sarana dan prasarana adalah proses pengelola sarana prasarana agar bermanfaat bagi lembaga untuk mencapai tujuan secara efektif dan efisien. Bafadal mendefenisikan manajemen sarana dan prasarana pendidikan sebagai proses kerja sama pendayagunaan semua sarana dan prasarana pendidikan secara efektif dan efisien. ${ }^{6}$ Menurut

${ }^{6}$ Ibrahim Bafadal, Manajemen Perlengkapa Sekolah: Teori dan Aplikasinya, (Jakarta: Bumi Aksara, 2008), hlm. 116. 


\section{คКค口EMIKค \\ Jurnal Manajemen Pendidikan Islam}

INSTITUT AGAMA ISLAM SUNAN KALIJOGO MALANG

P-ISSN 2622-9293 / E-ISSN 2721-9658

Volume 3 Nomor 1 Juni 2021

Tim Pakar Manajemen Universitas Negeri Malang, manajemen sarana dan prasarana adalah proses kerjasama pendayagunaan semua sarana dan prasarana pendidikan yang dimiliki oleh sekolah secara efektif dan efisisen. ${ }^{7}$ Dari beberapa defenisi di atas, dapat disimpulkan bahwa manajemen sarana dan prasarana pendidikan adalah proses kerjasama pendayagunaan semua sarana dan prasarana pendidikan yang dimiliki oleh sekolah dalam rangka pencapaian tujuan yang telah ditetapkan secara efektif dan efisisen. Manajemen sarana dan prasarana yang baik diharapkan dapat menciptakan sekolah yang bersih, rapi, indah, sehingga menciptakan kondisi yang menyenangkan baik bagi peserta didik, guru, dan tenaga kependidikan yang berada di sekolah. Manajemen sarana dan prasarana pendidikan meliputi perencanaan, pengorganisasian, pelaksanaan, pengawasaan, dan evaluasi kegiatan pengadaan barang, pembagian dan penggunaan barang (inventasi), perbaikan barang, dan tukar tambah maupun penghapusan barang. ${ }^{8}$

Adapun kegiatan manajemen sarana dan prasarana di MAN 3 Tulungagung yaitu meliputi:

\section{Pengadaan}

Adapun pada kegitan pengadaan barang di MAN 3 Tulungagung untuk memperoleh dananya yaitu dibantu oleh pemerintah dan sekolah tinggal meminta izin atau membuat proposal untuk memperoleh dana dan digunakan membeli barang yang dibutuhkan sekolah tersebut. Para wali murid MAN 3 Tulungagung membentuk suatu perkumpulan yang salah satu fungsinya membantu dalam pengadaan sarana dan prasarana sehingga memperlancar kegiatan belajar mengajar para siswa. Proses pengadaan tersebut sesuai dengan pendapat Bafadal, dimana dia mengungkapka proses pengadaan sarana prasarana adalah (1) Dropping dari pemerintah hal ini meruoakan bantuan yang diberikan permerintah kepada sekolah. Bantuan ini sifatnya terbatas sehingga pengelolaan sarana dan prasarana pendidikan disekolah tetapharus mengusahakan dengan cara lain. (2) Mengadakan sarana dan prasarana sekolah dengan cara membeli baik secara langsung maupun melalui pemesanan terlebih dahulu. (3) Meminta sumbangan dari wali murid atau mengajukan proposal bantuan pengadaan sarana dan prasarana sekolah ke lembaga-lembaga sosial yang tidak mengikat. (4) Mengadakan perlengkapan dengan cara menyewa atau meminjam ketempat lain. (5)

${ }^{7}$ Baharudin, Manajemen Pendidikan Islam, hlm. 83.

${ }^{8}$ Mulyono, Manajemen Administrasi dan Organisasi Pendidikan, (Solo: AR-RUZZ, 2010), hlm. 57. 


\section{RКЯDEMIKA \\ Jurnal Manajemen Pendidikan Islam}

INSTITUT AGAMA ISLAM SUNAN KALIJOGO MALANG

P-ISSN 2622-9293 / E-ISSN 2721-9658

Volume 3 Nomor 1 Juni 2021

Mengadakan perlengkapan sekolah dengan cara tukar menukar barang yang dimiiki denga barang lainnya yang dibuuhkan sekolah. ${ }^{9}$

Adapun bentuk sarana dan prasarana yang sudah diadakan oleh MAN 3 Tulungagung adalah sebagai berikut.

1. Sarana dan Prasarana Pembelajaran MAN 3 Tulungagung

Seperti yang telah disebutkan pada kondisi sarana prasarana di atas.

2. Bimbingan Konseling

Bimbingan konseling di MAN 3 Tulungagung dengan maksud untuk membantu dan melaksanakan pelayanan bimbingan dan konseling kepada siswa. Bimbingan konseling memiliki tiga sasaran dalam pembela jaran. 1. Untuk siswa kelas X; orientasi dan eksplorasi diri meliputi pengenalan sekolah, pemahaman diri, potensi diri, konsep diri, evaluasi diri, psikologi remaja, peranan IQ, EQ, AQ, dan SQ. 2. Untuk siswa kelas XI; pengembangan diri meliputi komunikasi, memasuki dunia pergaulan, etika/budi pekerti, EQ dan pengendalian diri, cara belajar efektif, kreativitas dan problem solving. 3. Untuk siswa kelas XII; pengambilan keputusan, meliputi: ESQ mendasari perencanaan masa depan, orientasi dan aspirasi jabatan karir, kemampuan umum, kemampuan khusus, minat, kepribadian, kemampuan akademik, merencanakan masa depan, analisis SWOT, dan tindak lanjut.

\section{Perpustakaan}

Perpustakaan sekolah merupakan bagian integral dari sekolah yang bertujuan menyediakan bahan pelajaran dan sumber informasi baik yang tercetak maupun tidak, layanan internet yang membantu badan induk. Perpustakaan ini bernaung untuk mencapai tujuan warga sekolah untuk mengembangkan wawasan.

a) Tujuan perpustakaan sekolah

Tujuan perpustakaan sekolah adalah menghimpun, mengumpulkan, mengolah bahan pustaka dengan system tertentu melalui pemeliharaan, penyimpanan, pelayanan dan pendayagunaan bahan pustaka untuk menunjang proses belajar mengajar di sekolah.

b) Fungsi perpustakaan

Perpustakaan berfungsi sebagai berikut.

1) Pusat kegiatan belajar mengajar

2) Tempat membantu siswa dalam memperjelas pengetahuan tentang pelajaran yang diterimanya di dalam kelas

${ }^{9}$ Ibrahim Bafadal, Manajemen Perlengkapan Sekolah Teori dan Aplikasinya, (Jakarta: Bumi aksara, 2004), hlm. 31. 
3) Pusat dalam penelitian sederhana

4) Tempat untuk memupuk daya kritis siswa

5) Pusat informasi

6) Tempat mengembangkan bakat, minat, dan kegemaran siswa

7) Pusat pengembangan apresiasi budaya

8) Tempat rekreasi

c) Fasilitas di perpustakaan MAN 3 Tulungagung

1) Ruang perpustakaan full AC

2) buku hampir lengkap

3) VCD pembelajaran

4) CD pembelajaran

5) Komputer

6) Televisi

7) DVD ROM + Burning CD-R/CD-RW

8) SuratKabar, Majalah, Brosur, Karya Tulis

4. Usaha Kesehatan Sekolah

Usaha Kesehatan Sekolah merupakan bagian dari kegiatan sekolah bidang non Akademik dengan tujuan terciptanya sekolah sehat dan bersih. Untuk terciptanya sekolah sehat dan bersih di MAN 3 Tulungagung dibentuk:
a) Kader Kesehatan Remaja (KKR)
b) Tim Pemberantasan Jentik Nyamuk
c) Trias UKS
d) Palang Merah Remaja (PMR)
e) Jasa Cleaning Service
f) Ruang UKS

\section{Penggunaan}

Setelah dilakukaan pengadaan sarana dan prasarana selanjutnya barang digunakan secara maksimal dengan tujuan untuk menunjang pencapaian tujuan lembaga. Hal ini dikarenakan semua sarana dan prasarana yang sudah ada sangat dibutuhkan dalam menunjang pelaksanaan proses belajar mengajar. Seperti penggunaan Lab komputer dilakukan penjadwalan tiap kelas. Sehingga setiap minggunya Lab komputer dapat dimanfaatkan secara maksimal. Manajemen pengadaan terkait penjadwalan tersebut sesuai 
dengan pendapat Suharsimi Arikunto yang menyebutkan sarana pendidikan untuk beberapa kelas yaitu apabila jumlah alat yang tersedia terbatas, padahal yang membutuhkan lebih dari satu kelas, maka alat-alat tersebut terpaksa digunakan bersama-sama secara bergantian. ${ }^{10}$

\section{Pemeliharan}

Seperti yang penulis ketahui berdasarkan pengalaman dulu selama sekolah di MAN 3 Tulungagung, pemeliharaan barang yang dilakukan MAN 3 Tulungagung terhadap semua fasilitas yang ada, disediakan anggaran sendiri. Dalam kegiatan pemeliharaan barang pada dilakukan oleh tenaga ahli dibidangnya. Jika terjadi kerusakan maka dilakukan perbaikan pada barang tersebut. Dalam kelas juga dilakukan pemeliharaan yang dilakukan oleh cleaning service yang sudah disediakan oleh sekolah.

\section{Peniadaan/Penghapusan}

Dalam hal peniadaan, lembaga tidak begitu saja membuang atau menghapus barangbarang yang sudah rusak atau sudah tidak bisa terpakai. Berhubung status sekolah ini negeri, jadi seluruh aset termasuk barang-barang itu merupakan milik Negara, meskipun uangnya berasal dari dana swadaya masyarakat. Maka ketika terjadi kerusakan atau mau diadakan penghapusan maka barang-barang tersebut dikembalikan ke Negara. Pemerintah daerah, khususnya pemerintah kota, disini bertindak sebagai penerima barang, yang selanjutnya barang-barang tersebut dilelang oleh Negara dan hasilnya juga kembali ke Negara. Hal tersebut bertolak belakang dengan pendapat Arikunto yang menyatakan penghapusan barang dapat dilakukan dengan cara-cara berikut.11

a) Penjualan, barang atau sarana pendidikan dijual.

b) Tukar menukar barang, barang yang tidak dipakai ditukarkan dengan barang baru atau sarana baru.

c) Dihibahkan, barang atau sarana pendidikan yang tidak dipakai dihibahkan kepada lembaga lain yang membutuhkan.

d) Dibakar, barang yang tidak mungkin dijual atau dihibahkan bisa dibakar.

D. Manajemen Sarana Dan Prasarana Pembelajaran Bahasa Arab Di MAN 3 Tulungagung

Adapun Sarana dan Prasarana Pembelajaran Bahasa Arab di MAN 3 Tulungagung adalah sebagai berikut.

\footnotetext{
${ }^{10}$ Suharsimi Arikunto \& Lia Yuliana, Manajemen Pendidikan, (Yogyakarta: Aditya Media, 2008),
} hlm. 278.

${ }^{11}$ Suharsimi Arikunto \& Lia Yuliana, Manajemen Pendidikan,...hlm. 282. 


\section{คКค口EMIKค \\ Jurnal Manajemen Pendidikan Islam}

INSTITUT AGAMA ISLAM SUNAN KALIJOGO MALANG

P-ISSN 2622-9293 / E-ISSN 2721-9658

Volume 3 Nomor 1 Juni 2021

1. Sarana Prasarana Pembelajaran Bahasa Arab

- Sarana: laptop, spidol, papan tulis, kartu bergambar, power point, benda-benda miniatur, benda-benda konkret, kaset, VCD Player, dan sebagainya.

- Prasarana: ruang kelas tertutup, internet, perpustakaan, taman, LAB.

2. Proses menejemen sarana prasarana PBA di MAN 3 Tulungagung

\section{a) Pengadaan}

Adapun pada kegitan pengadaan sarana prasarana PBA di MAN 3 Tulungagung sama dengan pengadaan sarana prasarana untuk pembelajaran mata pelajaran lain yaitu dibantu oleh pemerintah dan sekolah tinggal meminta izin atau membuat proposal untuk memperoleh dana dan digunakan membeli barang yang dibutuhkan sekolah tersebut. Disamping itu para wali murid MAN 3 Tulungagung membentuk suatu perkumpulan yang salah satu fungsinya membantu dalam pengadaan sarana dan prasarana sehingga memperlancar kegiatan belajar mengajar para siswa.

\section{b) Penggunaan}

Setelah dilakukaan pengadaan sarana dan prasarana selanjutnya barang digunakan secara maksimal dengan tujuan untuk menunjang pencapaian tujuan lembaga. Hal ini dikarenakan semua sarana dan prasarana yang sudah ada sangat dibutuhkan dalam menunjang pelaksanaan proses belajar mengajar. Seperti penggunaan Lab bahasa Arab dilakukan penjadwalan tiap kelas. Sehingga setiap minggunya Lab bahasa Arab dapat dimanfaatkan secara maksimal.

Manajemen pengadaan terkait penjadwalan Lab bahasa Arab tersebut sesuai dengan pendapat Suharsimi Arikunto yang menyebutkan sarana pendidikan untuk beberapa kelas yaitu apabila jumlah alat yang tersedia terbatas, padahal yang membutuhkan lebih dari satu kelas, maka alat-alat tersebut terpaksa digunakan bersama-sama secara bergantian. ${ }^{12}$

\section{c) Pemeliharan}

Seperti yang penulis ketahui berdasarkan pengalaman dulu selama sekolah di MAN 3 Tulungagung, pemeliharaan sarana prasarana bahasa Arab yang dilakukan MAN 3 Tulungagung terhadap semua fasilitas yang ada, disediakan anggaran sendiri. Dalam kegiatan pemeliharaan barang pada dilakukan oleh tenaga ahli dibidangnya. Jika terjadi kerusakan maka dilakukan perbaikan pada barang tersebut. Dalam kelas juga dilakukan pemeliharaan yang dilakukan oleh cleaning service yang sudah disediakan oleh sekolah.

\footnotetext{
${ }^{12}$ Suharsimi Arikunto \& Lia Yuliana, Manajemen Pendidikan, hlm. 278.
} 


\section{d) Peniadaan/Penghapusan}

Dalam hal peniadaan sarana prasarana pendidikan bahasa Arab sama dengan dengan peniadaan sarana prasarana secara keseluruhan, yaitu MAN 3 Tulungagung tidak begitu saja membuang atau menghapus barang-barang yang sudah rusak atau sudah tidak bisa terpakai. Berhubung status sekolah ini negeri, jadi seluruh aset termasuk barang-barang itu merupakan milik Negara, meskipun uangnya berasal dari dana swadaya masyarakat. Maka ketika terjadi kerusakan atau mau diadakan penghapusan maka barang-barang tersebut dikembalikan ke Negara. Pemerintah daerah, khususnya pemerintah kota, disini bertindak sebagai penerima barang, yang selanjutnya barang-barang tersebut dilelang oleh Negara dan hasilnya juga kembali ke Negara.

\section{E. Kesesuaian Sarana Prasarana Di MAN 3 Tulungagung Dengan Standar Nasional Pendidikan}

Sebagai Sekolah Standar Nasioanl (SSN) MAN 3 Tulungagung secara garis besarnya sudah sesuai dengan standar nasional pendidikan. Hal ini di buktikan dengan adanya sarana prasarana yang menunjang siswa untuk dapat mengembangkan pembelajarannya dan keterampilan masing - masing individu. Kemampuan struktur manajerial sudah sangat baik dibuktikan dengan berfungsinya wakasek sarana dan prasarana, meskipun dalam beberapa hal masih memerlukan pembenahan seperti halnya rekapitulasi data prasarana yang akurat secara terpusat di bagian sarana prasarana.

Kesesuaian sarana dan prasarana dengan diperolehnya akreditasi A. Nilai yang diperoleh untuk standar sarana dan prasarana adalah sebesar 97,50. Hal ini menandakan sarana dan prasarana sudah sesuai dengan standar nasional pendidikan.

Jika dilihat dengan standar kurikulum dan juga kesesuaian antar kurikulum yang diterapkan dan kondisi sarana prasarana di MAN 3 Tulungagung maka sudah mencukupi standar minimum. Namun pihak sekolah juga terus mengadakan program peningkatan baik dalam pengadaan, perawatan dan juga penghapusan sarana dan prasarana yang tersedia. 


\section{PENUTUP}

\section{Kesimpulan}

Sarana pendidikan adalah fasilitas-fasilitas yang digunakan secara langsung dalam proses belajar mengajar agar tujuan pembelajaran tercapai. Sedangkan prasarana pendidikan merupakan segala sesuatu yang secara tidak langsung menunjang proses pendidikan. Di MAN 3 Tulungagung sudah memenuhi standar nasional pendidikan dengan sarana dan prasara yang baik. Hal ini dibuktikan dengan adanya pengalaman penulis selama menempuh pendidikan di sekolah tersebut. Sarana dan prasarana yang sudah tersedia di MAN 3 Tulungagung membuat para siswa terfasilitasi dengan baik untuk mengembangkan keterampilan dan kemampuan individunya.

\section{Saran}

Hendaknya dalam memanajemen sarana dan prasarana pendidikan khususnya sarana prasarana pembelajaran bahasa Arab di MAN 3 Tulungagung harus direncanakan dengan matang dan harus diinventaris secara terpusat dan akurat sehingga dapat memudahkan dalam proses pendataan. 


\section{DAFTAR RUJUKAN}

Arikunto, Suharsimi \& Lia Yuliana. 2008. Manajemen Pendidikan. Yogyakarta: Aditya Media.

B. Sury dan Subroto. 1988. Dimensi-dimensi Administrasi Pendidikan di Sekolah. Jakarta :Bina Aksara.

Bafadal, Ibrahim. 2004. Manajemen Perlengkapa Sekolah: Teori dan Aplikasinya. Jakarta: Bumi Aksara.

Bafadal, Ibrahim. 2008. Manajemen Perlengkapa Sekolah: Teori dan Aplikasinya. Jakarta: Bumi Aksara.

Baharudin \& Moh. Makin. 2010. Manajemen Pendidikan Islam Trnsformasi Menuju Sekolah/Madrasah Unggul. Yogyakarta: UIN-Maliki Press.

Mulyono. 2010. Manajemen Administrasi dan Organisasi Pendidikan. Solo: AR-RUZZ.

Piet dan A. Sahertian.1994. Dimensi Administrasi Pendidikan. Surabaya:Usaha Nasional. 1994. 